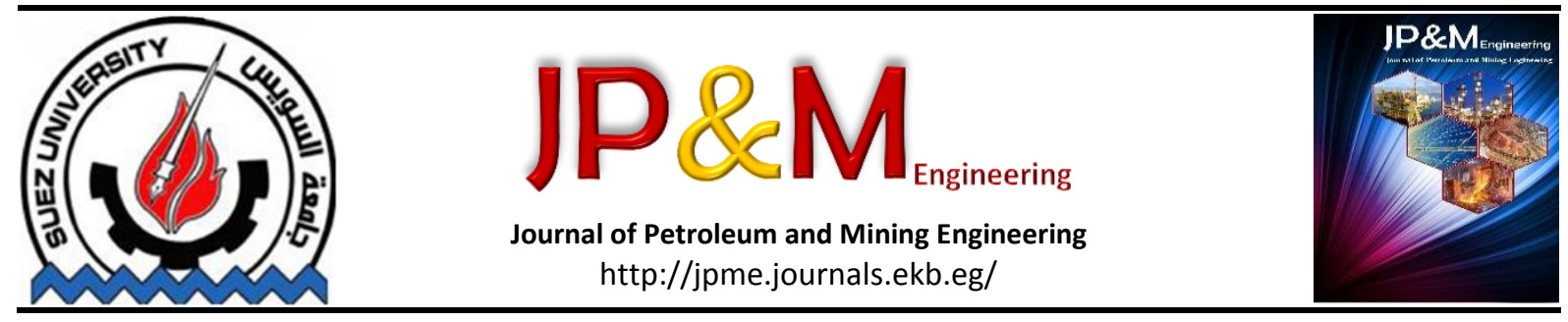

\title{
Simulation of Multi-Stage Flash with Brine Circulating Desalination Plant
}

\author{
Mohamed H. M. Hassanean, Ahmed S. Nafey. , Rehab M.El-Maghraby, Fatma M.Ayyad* \\ Faculty of Petroleum and Mining Eng., Suez University, Suez, Egypt. \\ *Corresponding author Fatma.ayyad@suezuniv.edu.eg
}

\section{Keywords}

Steady-state modelling; System of non-linear equations;Tri-diagonal matrix; System performance; Multi-stage Flash Desalination.

\begin{abstract}
Multi-stage flash (MSF) desalination is the main process to solve the problem of limited freshwater resources in the world. This work describes the developed steady-state mathematical model for analysing and evaluating the performance of Multistage flashing with brine circulation desalination process (MSF-BC). It is based on the laws of energy balance, material balance, and heat transfer equations with physical properties correlations equations. The nonlinear equations are linearized and arranged into a tridiagonal matrix form. The model solution is obtained by a computer code written by MATLAB program software. It can predict the productivity of the plant with temperature profiles and flow rates for all stages in the unit. The model results were compared with some previous results presented in literature. The comparison shows good agreement with these available data. An MSF desalination plant in Ayoun Mousa, Egypt of capacity 5000 $\mathrm{m}^{3} /$ day was presented as a case study.
\end{abstract}

\section{Introduction}

Water plays an important role in all aspects of life including industrial activities.Drinking water is unfairly similar to most other natural resources, which are distributed unequally around the world.

There is increasing worldwide concern about the scarcity of global water resources, day by day. So, desalination of seawater became a major solution for providing arid zones with continuous supply of fresh water.

Multi-stage flash desalination(MSF) is one of the major method for the desalination industry with a market share of around $60 \%$ of the total production capacity worldwide (1).

The MSF desalination process is based on flash evaporation, depends on using vaporization through multi-stage chambers. The MSF desalination process has many advantages such as it can produce high quality of freshwater with TDS of less than $30 \mathrm{ppm}$. The produced water can be used in many purposes like boiler making water, chemical processes, dairy and food washing, cooling and cleaning (2). Besides the high-water quality, it produces large quantities of fresh water up to $75000 \mathrm{~m}^{3} / \mathrm{d}$ for each unit.

The MSF desalination plants are composed of two models (3), Once-through MSF (MSF-OT) which consist of two sections (brine heater and heat recovery sections) and
Brine recirculation MSF (MSF-BC) which has one extra section (heat rejection section).

Many researches were conducted to enhance the operation of MSF desalination plants as efficiently as possible and, as a result, to reduce the cost of water generated from such plants. Part of this work focuses on mathematical modelling as a cheap alterative for industrial scale applicative. Models of MSF process can be classified into two different categories; Steady state models (simple and rigorous) and dynamic models.

The steady state mathematical model of MSF-BC process that based on the basic laws of thermodynamics is established in the literature. Models can sort from simple steady-state models with constant thermophysical properties of fluid streams $(4 ; 5 ; 6 ; 7 ; 8$; 9) to rigorous mathematical models which taking into account the variation of the thermo-physical properties of various fluids with temperature and salinity $(10 ; 11 ; 12$; $13 ; 14 ; 15 ; 16 ; 17 ; 18 ; 19) .(20 ; 21 ; 22 ; 23 ; 24)$

The main aim of this paper is to provide an algorithm for solving the large system of algebraic and nonlinear equations which is a rigorous steadystate mathematical model for MSF-BR. The system will be solved through Linearizing the equations into tri-diagonal matrix form (TDM) using MATLAB software. The results were verified against previous simulation data given by Abdul Wahab, (2012) (25), In addition, we studied the performance of actual desalination plant of Ayoun Mousa, Egypt (26). 


\section{Process Description}

The MSF process with brine circulation is shown in Figure 1 (21). The process is divided into three sections: the brine heater, the heat recovery and the heat rejection sections. Stages of heat recovery include heating of the recycled brine stream inside the condenser tubes from the brine blowdown temperature to a higher temperature near to the top brine temperature. So, the amount of steam used in the brine heater is minimized. The heat rejection section consists of three stages. The function of the heat rejection section is to monitor the feed seawater temperature and reject the excess heat added in the brine heater. Feed seawater enters the last stage of the heat rejection section (Fsea) and move through the condenser tubes to remove heat from the stages. The stream leaving the first stage of the heat rejection section is separated into two streams; the rejected seawater $(\mathrm{CW})$ and the makeup stream (F) which is mixed with recycled brine $(R)$ from the last stage of the heat rejection section. Cooling brine (W) enters the last stage of the heat recovery section. It heats gradually by the flashing brine in each stage and leaves the heat recovery section from the first stage. Then it enters the brine heater to raise its temperature to the top brine temperature (TBT) and enters into the $1^{\text {st }}$ flashing stage and produce flashing vapor. This continuous till the last stage of the heat rejection section. The brine stream (BN) from the last stage is spilt into two streams: the blowdown $(B D)$ stream that is settled to the sea and the remaining recycled water stream $(R)$ which is recycled back to mix with the makeup flow. The distillate is collected from each stage to produce the freshwater product at the end (DN).

\section{Mathematical Model}

The following_simplifying assumptions were used in the rigorous steady state modelling,

- Steady_state_operation is the common_assumption amongst all studies. (18) .

- The distillate is free from salt.

- Heat losses to the_surroundings are insignificant.

- Brine holdup and brine flow rate are considered as constant along the unit.

- Heat transfer area shall be considered the same for each part of the plant.

- The physical_properties such as heat capacity, viscosity, brine densities, boiling temperatures, vapor enthalpy temperature, and heat transfer coefficient depend on temperature and salinity variation.

- Thermodynamic losses include the boiling point elevation (BPE), the non-equilibrium allowance (NEA), and demister losses (DEM).

- The effect of non-condensable gases on heat transfer is negligible.

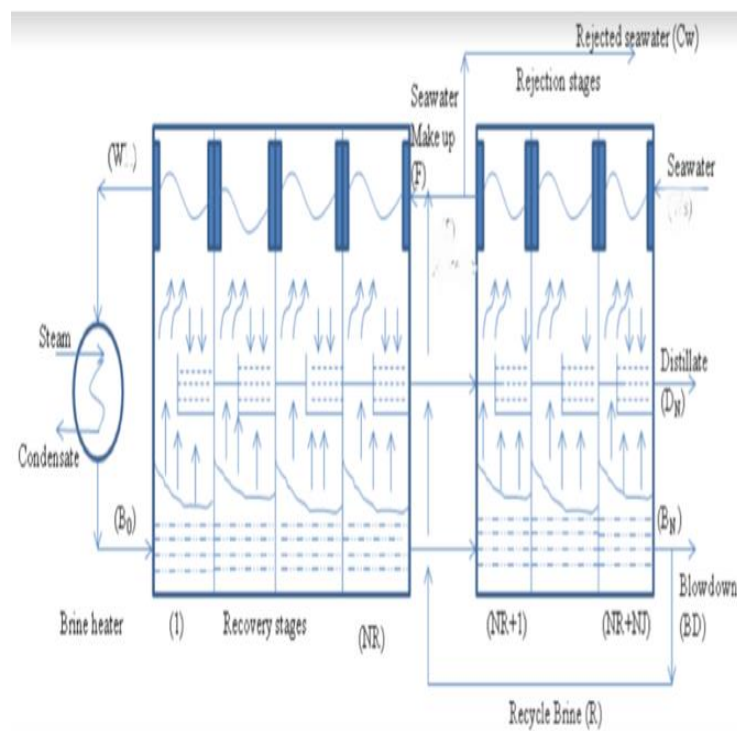

Figure 1: Multistage Flash Desalination Brine process circulation (MSF-BC)

- Heat from mixing is negligible due to the low $\mathrm{NaCL}$ heat of mixing

The steady-state model equations consist of a set of energy and material balance equations which include the following (25):

- Overall material balance equations.

- Material balance equation for each stage.

- Salt_balance_equation for each stage.

- Enthalpy balance equations on flashing brine

- Overall enthalpy balance for any stage.

- Brine heater model.

- Mixing and splitting equations.

Schematics of the MSF variables in the flashing_stage_and the_brine_heater are shown in Figures 2 and 3 (21).

\section{Overall Material Balance Equations}

As shown in Figure 1 (21), the overall mass balance for MSF desalination plant is given by,

$$
F_{s e a}=C_{w}+D_{N}+B_{N}
$$

The material balance for the splitter is given by,

$$
C_{w}=F_{\text {sea }}-F
$$

Substituting Equation 2 into Equation 1 yields,

$$
F+D_{N}+B_{D}
$$

The overall material balance for the MSF plant as shown in Equation 3 has one input stream and two output streams. The overall salt balance is given by,

$$
F X_{F}=B_{D} X_{B N}
$$

It should be noticed that the Equation 4 assumes that the distillate is free from salt. 


\section{Material and Salt Balance Equations for Each Stage}

The summation of the inlet flashing brine and distillate flow rates will be equal to the summation of those streams leaving the stage $(\mathrm{j})$.

Mass Balance in the flash chamber

$$
B_{j-1}+D_{j-1}=B_{j}+D_{j}
$$

Stage salt balance:

$$
B_{j-1} X_{B j-1}=B_{j} X_{B j}
$$

Mass balance for distillate tray

$$
\sum_{K=1}^{j} D_{k}=\sum_{K=1}^{j-1} D_{k}+D_{J}
$$

Enthalpy Balance Equations on Flashing Brine

For the flashing brine at stage (j), the enthalpy balance equation is given by,

$$
B_{j-1} h_{B j-1}=B_{j} h_{B j}+\left(B_{j-1}-B_{j}\right) h_{v j}
$$

\section{Overall Enthalpy Balance for Any Stage}

For a steady-state operation, the summation of the enthalpies of all input streams for stage (j) should be equal to the summation of all streams leaving the stage. There is no generation or accumulation of energy in the stage. The overall enthalpy balance for any stage (j) is given by:

$$
\begin{aligned}
& W S_{R j}\left(T_{F j}-T_{F j+1}\right)= \\
& D_{j-1} S_{D j-1}\left(T_{D j-1}-T^{*}\right)+ \\
& B_{j-1} S_{B j-1}\left(T_{B j-1}-T^{*}\right)- \\
& D_{j} S_{D j}\left(T_{D j}-T^{*}\right)-B_{j} S_{B j}\left(T_{B j}-T^{*}\right)
\end{aligned}
$$

Where,

The specific heat capacity of pure saturated water (SDj) (29) is given by,

$$
\begin{aligned}
& S_{D j}=(1.001183- \\
& 6.61666652 * 10^{-5} T_{D j}+ \\
& 1.3999989 * 10^{-7} T_{D j}^{2}+ \\
& \left.1.3333336 * 10^{-9} T_{D j}^{3}\right) 4.184
\end{aligned}
$$

The specific heat capacity of flashing brine at each stage (SBj) (29) given by,

$S_{B j}=(4.185-5.381 *$

$\left.10^{-3} X_{B j}+6.26 * 10^{-6} X_{B j}^{2}\right)-$

$\left(3.055 * 10^{-5}+2.774 *\right.$

$$
\begin{aligned}
& \left.10^{-6} X_{B j}-4.318 * 10^{-8} X_{B j}^{2}\right) T_{B j}+ \\
& \left(8.844 * 10^{-7}+6.527 *\right. \\
& \left.10^{-8} X_{B j}-4.003 * 10^{-10} X_{B j}^{2}\right)
\end{aligned}
$$

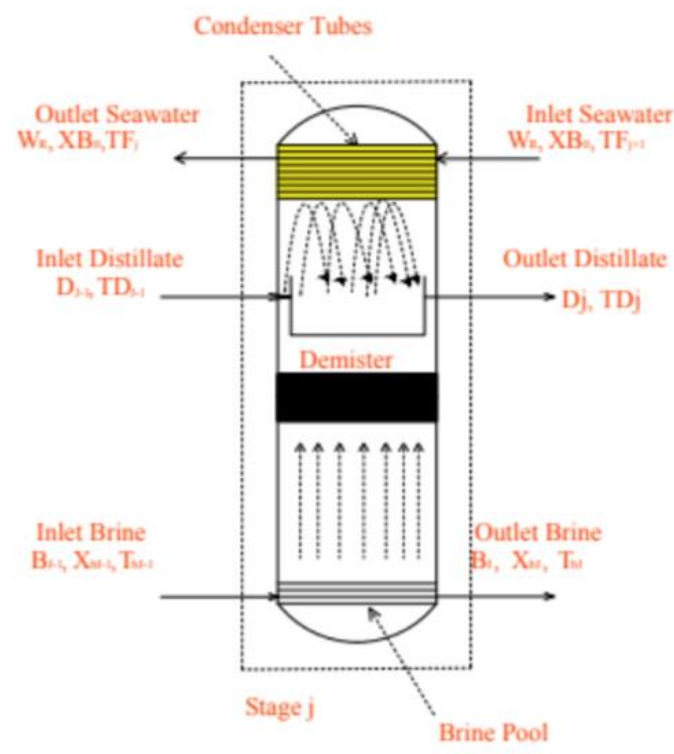

Figure 2: A general stage in an MSF plant

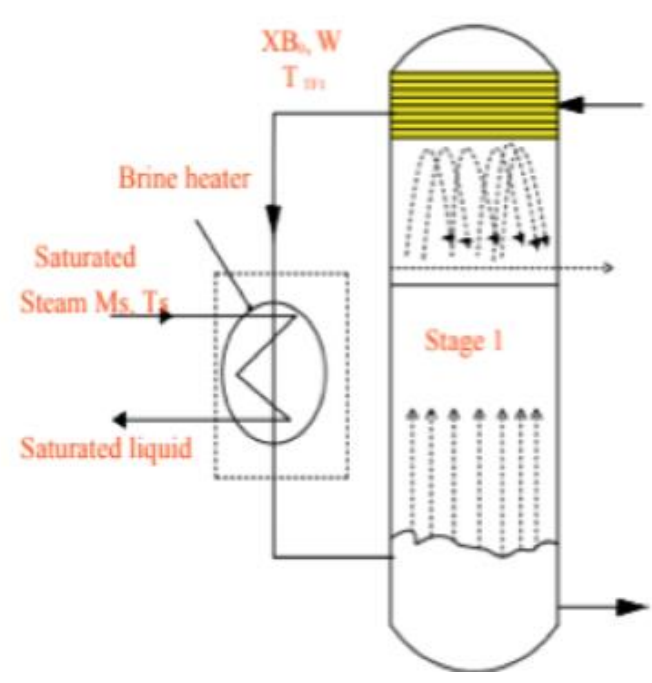

Figure 3: Typical brine heater

\section{Heat Transfer Equation}

The heat transferred to the cooling condenser tubes owing to condensation of the flashed vapor in stage(j). Heat transfer equation in the heat recovery section is given by:

$$
W S_{R j}\left(T_{F j}-T_{F j+1}\right)=U_{j} A_{j} L M T D_{j}
$$

In the heat rejection section, replacing $\mathrm{W}$ instead of Fsea. The logarithmic mean temperature difference in the recovery and rejection stages. 


$$
T_{v j}=T_{D j}+D E M
$$

$$
L M T D_{j}=\left(T_{F j}-T_{F j+1}\right) / \ln \left\{\frac{T_{D j}-T_{F j+1}}{T_{D j}-T_{F j}}\right\}
$$

\section{Equilibrium Equation}

The distillate and flashing brine temperature correlation is given by,

$$
T_{B j}=T_{D j}+B P E+N E A+D E M
$$

Where,

\section{Boiling Point Elevation (28)}

The boiling point elevation correlation of seawater is given by,

$$
\begin{aligned}
& B P E=A X+B X^{2}+C X^{3} \\
& A=\left(8.25 * 10^{-2}+1.883 *\right. \\
& \left.10^{-4} T+4.02 * 10^{-6} T^{2}\right) \\
& B=\left(-7.625 * 10^{-4}+9.02 *\right. \\
& \left.10^{-5} T-5.2 * 10^{-7} T^{2}\right) \\
& C=\left(1.522 * 10^{-4}-3 * 10^{-6} T-3 *\right. \\
& 10^{-8} T^{2}
\end{aligned}
$$

Where $\mathrm{X}$ is the weight percentage of the salt and $\mathrm{T}$ is the temperature in ${ }^{\circ} \mathrm{C}$.

\section{Non-equilibrium allowance (28)}

The NEA correlation for the MSF system is given by,

$$
\begin{aligned}
& N E A= \\
& \left(\frac{N E A_{10}}{0.5 \Delta T+N E A_{10}}\right)^{0.3281 L}\left(0.5 \Delta T+N E A_{10}\right) \\
& N E A_{10} \\
& =(0.9784)^{T i}(15.7378)^{H}(1.3777)^{V b * 10^{-6}}
\end{aligned}
$$

\section{Demister and Other Losses (31)}

The temperature loss that follows the pressure drop through the demister and condenser tubes is calculated from the following equation:

$$
D E M=\frac{\operatorname{Exp}\left(1.885-0.02063\left(1.8 T_{D j}+32\right)\right)}{1.8}
$$

The distillate flashed steam temperature correlation is given by,

\section{Brine Heater Model}

As shown in the Figure 4, the performance of brine heater can be described as

Mass balance (brine):

$$
\boldsymbol{W}=\boldsymbol{B}_{\boldsymbol{o}}
$$

Overall enthalpy balance:

$$
B_{o} S_{R j}\left(T_{B o}-T_{F 1}\right)=M_{s} \lambda_{s}
$$

Where,

The latent heat of vaporization (28) is given by,

$$
\begin{aligned}
& \lambda_{s}=2501.897149- \\
& 2.407064037 T+1.192217 * \\
& 10^{3} T^{2}-1.5863 * 10^{5} T^{3}
\end{aligned}
$$

Heat transfer equation in the brine heater:

$$
W S_{R H}\left(T_{B o}-T_{F 1}\right)=U_{H} A_{H} L M T D_{H}
$$

The heat transfer coefficient for the brine and vapor side (31) is given by,

$$
U=\frac{4.8857}{y+z+4.8857 F_{f j}}
$$

Where,

$$
\begin{aligned}
& z=0.102 * 10^{-2}-0.747 * \\
& 10^{-5} T_{D j}+0.997 * 10^{-7} T_{D j}^{2}- \\
& 0.430 * 10^{-9} T_{D j}^{3}+0.620 * \\
& 10^{-12} T_{D j}^{4} \\
& y=\frac{\left(V_{B j} I D_{j}\right)^{0.2}}{\left(160+1.92 T_{B j}\right) V_{B j}}
\end{aligned}
$$

The logarithmic mean temperature difference for the brine heater (LMTDj)

$$
L M T D_{H}=\left(T_{B o}-T_{F 1}\right) / \ln \left\{\frac{T_{s}-T_{F 1}}{T_{s}-T_{B o}}\right\}
$$

\section{Mixer and Splitter Model}

Mass balance on mixer:

$$
\boldsymbol{W}=\boldsymbol{F}+\boldsymbol{R}
$$

Salt balance on mixer:

$$
W X_{B o}=F X_{F}+R X_{B N}
$$


Enthalpy balance on mixer:

$$
W h_{M}=R h_{R}+F h_{F}
$$

At splitting point:

$$
B_{D}=B_{N}-R
$$

Where,

The specific enthalpy of saturated water (30) is given by,

$$
\begin{aligned}
& h_{D j}=\left(1.001183 T_{D j}-\right. \\
& 3.0833326 * 10^{-5} T_{D j}^{2}+ \\
& 4.666663 * 10^{-8} * T_{D j}^{3}+ \\
& 3.333334 * 10^{-10} T_{D j}^{4}-
\end{aligned}
$$$$
\text { 31. } 92)\left(\frac{4.184}{1.8}\right)
$$

The water vapor enthalpy is given by,

$$
h_{v}=2499.15+1.955 T-
$$$$
1.927 * 10^{-3} T^{2}
$$

The specific enthalpy of brine at each stage given by,

$$
\begin{aligned}
& h_{B j}=(4.185-5.381 * \\
& \left.10^{-3} X_{B j}+6.26 * 10^{-6} X_{B j}^{2}\right) T_{B j}- \\
& \left(3.055 * 10^{-5}+2.774 *\right. \\
& \left.10^{-6} X_{B j}-4.318 * 10^{-8} X_{B j}^{2}\right) T_{B j}^{2}+ \\
& \left(8.844 * 10^{-7}+6.527 *\right. \\
& \left.10^{-8} X_{B j}-4.003 * 10^{-10} X_{B j}^{2}\right) T_{B j}^{3}
\end{aligned}
$$

\section{Solution of the Systems of Equations}

The above mentioned equations composed of algebraic and nonlinear equations. The linearization of MSF-BC plant equations suggested by Helal et al. (10), into tridiagonal matrix arrangement (TDM form) was selected in this work since this approach has the following advantages (26):

- The algorithm has high degree of convergence stability and results in shorter run times compared with calculation approaches which follow stage wise.

- Small number of iterations required

The final form of TDM for stage(j) in the recovery and rejection sections is:

$$
\begin{aligned}
& A y_{j} T_{F j-1}+B e_{j} T_{F j}+C e_{j} T_{F j+1}= \\
& D e_{j}
\end{aligned}
$$

Where,

$$
\begin{aligned}
& A y=c_{1 j} \\
& B e=c_{2 j}-1
\end{aligned}
$$

$$
\begin{aligned}
& C e=c_{3 j}+1 \\
& D e=-b_{3 j}
\end{aligned}
$$

Where,

$$
\begin{aligned}
& c_{1 j}=-\left(\frac{b_{1 j} \alpha_{j-1}}{1-\alpha_{j-1}}\right) \\
& c_{2 j}=\left(\frac{b_{1 j}}{1-\alpha_{j-1}}\right)-\left(\frac{b_{2 j} \alpha_{j}}{1-\alpha_{j}}\right) \\
& c_{3 j}=\frac{b_{2 j}}{1-\alpha_{j}}
\end{aligned}
$$

Where,

$$
\begin{aligned}
& b_{1 j}=a_{1 j}+a_{2 j} \\
& b_{2 j}=-\left(a_{3 j}+a_{4 j}\right) \\
& b_{3 j}=a_{5 j}+a_{2 j} Z_{j-1}-a_{4 j} Z_{j}
\end{aligned}
$$

Where,

$$
\begin{aligned}
& a_{1 j}=\frac{D_{j-1} * S_{D j-1}}{W * S_{R j}} \\
& a_{2 j}=\frac{B_{j-1} * S_{B j-1}}{W * S_{R j}} \\
& a_{3 j}=\frac{D_{j} * S_{D j}}{W * S_{R j}} \\
& a_{4 j}=\frac{B_{j} * S_{B j}}{W * S_{R j}}
\end{aligned}
$$

The mathematical model for a steady state process, as described above, is used to build MATLAB code for performance analysis of MSF desalination systems. Figure 4 gives the flow chart of the model solution steps used for steady state simulation of the MSF desalination systems by tridiagonal matrix.

\section{Model Validation}

Figures (5 and 6) Compare the temperatures of the flashing brine (TBj), distillate (TDj), and recirculating brine (TFj) in 24 flashing stages of simulation results reported by Abdul Wahab, (2012) (25) based on Barka MSF desalination plant data with values predicted by developed model. The results show a good agreement. 


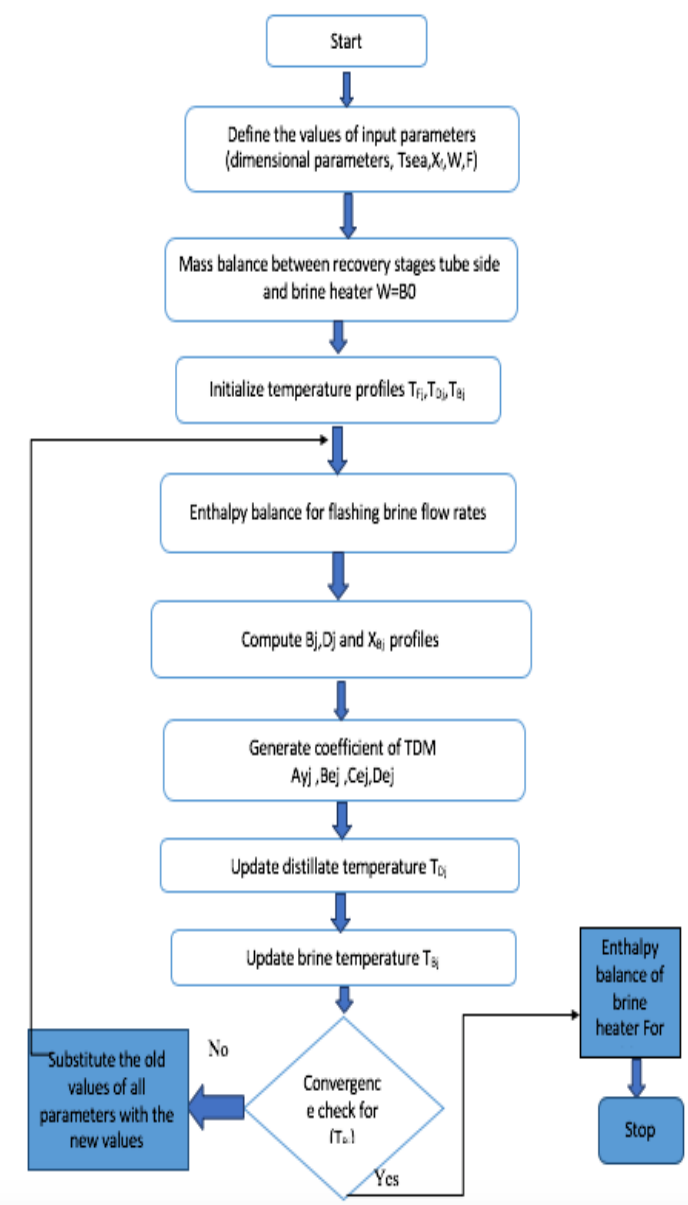

Figure 4: The flow chart for the solution of the developed model (TDM)

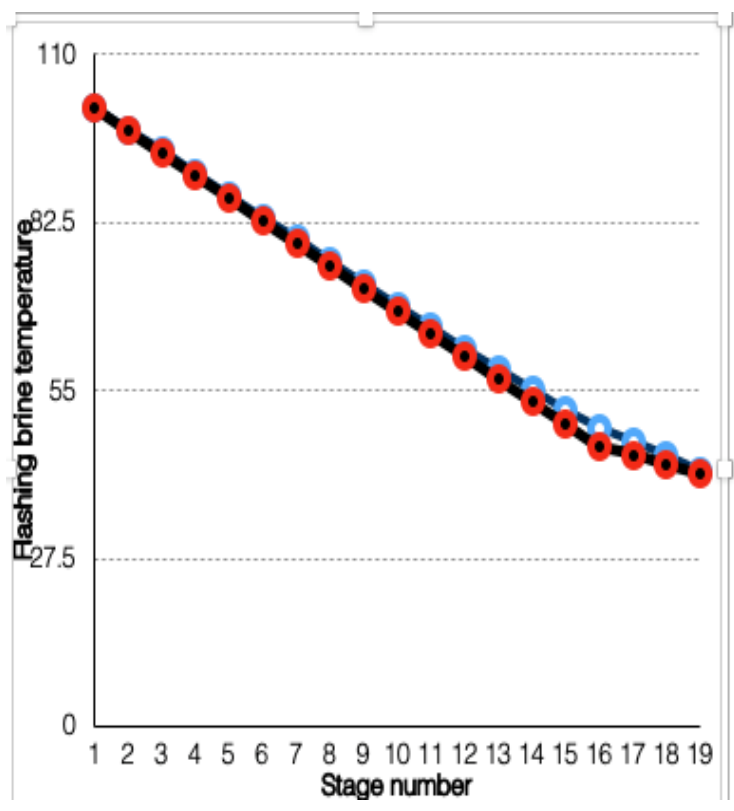

Figure 5: Comparison of our work with AbdulWahab(2012) for flashing stage temperature(TBj)

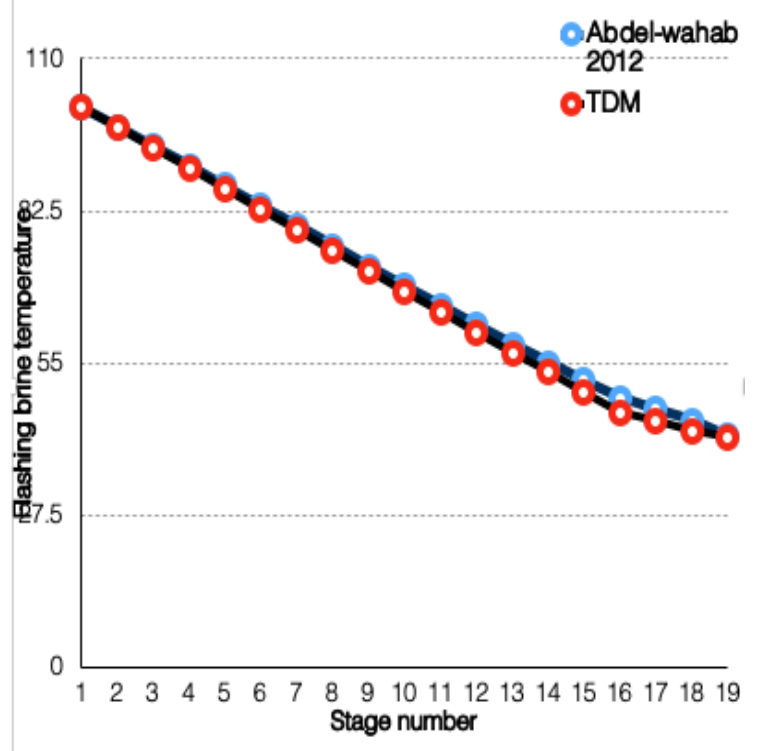

Figure 6: Comparison of our work with AbdulWahab(2012) for distillate temperature(TDj)

\section{Results}

The presented model was useful to simulate the production of Ayoun Mousa MSF plant in Egypt. The capacity of the unit is $5000 \mathrm{~m}^{3} /$ day and the operating conditions are listed in Table 1 (27). Initial guessing values of the mass flow rates and the temperatures of all the process streams were obtained from simple mathematical model suggested by El-Dessouky and Ettouney (2002)(28).After demonstrating the capability of the developed model, it is used to measure the productivity with the profiles of temperatures and flow rates in all the stages of the unit. The simulation results for the operating parameters of this work is shown in the Table 2.

Table 1: Design and operational data for Ayoun Mousa MSF desalination plant.

\begin{tabular}{|l|l|}
\hline $\mathbf{5 0 0 0} \mathrm{m}^{\mathbf{3}}$ /day MSF_BC \\
\hline Top brine temperature (TBT) ${ }^{\circ} \mathrm{C}$ & 110 \\
Brine blowdown temperature ${ }^{\circ} \mathrm{C}$ & 39 \\
Feed seawater temperature ${ }^{\circ} \mathrm{C}$ & 27 \\
Cooling water splitter ratio & 0.482 \\
Sea water salinity, ppm & 48000 \\
Brine blow down salinity, ppm & 70000 \\
Number of stages & $20\left(\mathrm{~N}_{\mathrm{R}}=17, \mathrm{~N}_{\mathrm{j}}=3\right)$ \\
Brine load $\mathrm{Kg} / \mathrm{m} . \mathrm{s}$ & 180 \\
Vapor velocity $\mathrm{m} / \mathrm{s}$ & 12 \\
Weir coefficient Cd & 0.5 \\
Tube outside diameter, $\mathrm{m}$ & 0.02199 \\
Tube inside diameter, $\mathrm{m}$ & 0.01949 \\
BH outside diameter, $\mathrm{m}$ & 0.0239 \\
BH inside diameter, $\mathrm{m}$ & 0.0214 \\
\hline
\end{tabular}

Table 2: Model predictions for this operating condition of this work. 


\begin{tabular}{|c|c|c|c|c|c|c|}
\hline$j$ & $\begin{array}{l}\mathrm{T}_{\mathrm{Bj}}, \\
{ }^{\circ} \mathrm{C}\end{array}$ & $\mathrm{T}_{\mathrm{Dj},}{ }^{\circ} \mathrm{C}$ & $T_{\mathrm{Fj},}{ }^{\circ} \mathrm{C}$ & $\begin{array}{c}B_{j} \\
\mathrm{~kg} / \mathrm{s}\end{array}$ & $\begin{array}{c}D_{j} \\
\mathrm{~kg} / \mathrm{s}\end{array}$ & $\begin{array}{c}X_{j} \\
w t \%\end{array}$ \\
\hline 1 & $\begin{array}{c}106 . \\
45\end{array}$ & $\begin{array}{c}105.2 \\
28\end{array}$ & $\begin{array}{c}102.71 \\
47\end{array}$ & $\begin{array}{c}480.2 \\
5\end{array}$ & 3.071 & $\begin{array}{c}62.4 \\
6\end{array}$ \\
\hline 2 & $\begin{array}{c}102 . \\
9\end{array}$ & $\begin{array}{c}101.6 \\
71\end{array}$ & $\begin{array}{c}99.121 \\
2\end{array}$ & $\begin{array}{c}477.2 \\
2\end{array}$ & 6.122 & $\begin{array}{c}62.8 \\
6\end{array}$ \\
\hline 3 & 99.3 & $\begin{array}{c}98.06 \\
01\end{array}$ & $\begin{array}{c}95.489 \\
4\end{array}$ & $\begin{array}{c}474.2 \\
07\end{array}$ & 9.154 & $\begin{array}{c}6.32 \\
6\end{array}$ \\
\hline 4 & $\begin{array}{c}95.6 \\
2\end{array}$ & $\begin{array}{c}94.36 \\
52\end{array}$ & $\begin{array}{c}91.787 \\
3\end{array}$ & $\begin{array}{c}471.2 \\
13\end{array}$ & $\begin{array}{c}12.16 \\
7\end{array}$ & $\begin{array}{c}6.36 \\
62\end{array}$ \\
\hline 5 & $\begin{array}{c}91.9 \\
6\end{array}$ & $\begin{array}{c}90.68 \\
57\end{array}$ & $\begin{array}{c}88.111 \\
9\end{array}$ & $\begin{array}{c}468.2 \\
38\end{array}$ & $\begin{array}{c}15.16 \\
19\end{array}$ & $\begin{array}{c}6.40 \\
67\end{array}$ \\
\hline 6 & $\begin{array}{c}88.2 \\
7\end{array}$ & $\begin{array}{c}86.97 \\
11\end{array}$ & 84.41 & $\begin{array}{c}465.2 \\
81\end{array}$ & $\begin{array}{c}18.13 \\
7\end{array}$ & $\begin{array}{c}6.44 \\
74\end{array}$ \\
\hline 7 & $\begin{array}{c}84.5 \\
9\end{array}$ & $\begin{array}{c}83.26 \\
07\end{array}$ & $\begin{array}{c}80.718 \\
2\end{array}$ & $\begin{array}{c}462.3 \\
44\end{array}$ & $\begin{array}{c}21.09 \\
35\end{array}$ & $\begin{array}{c}6.48 \\
84\end{array}$ \\
\hline 8 & 80.9 & $\begin{array}{c}79.53 \\
37\end{array}$ & $\begin{array}{c}77.013 \\
6\end{array}$ & $\begin{array}{c}459.4 \\
24\end{array}$ & $\begin{array}{c}24.03 \\
12\end{array}$ & $\begin{array}{c}6.52 \\
96\end{array}$ \\
\hline 9 & $\begin{array}{c}77.2 \\
2\end{array}$ & $\begin{array}{c}75.80 \\
92\end{array}$ & $\begin{array}{c}73.313 \\
6\end{array}$ & $\begin{array}{c}456.5 \\
24\end{array}$ & $\begin{array}{c}26.95 \\
04\end{array}$ & $\begin{array}{c}6.57 \\
11\end{array}$ \\
\hline 1 & $\begin{array}{c}73.5 \\
6\end{array}$ & $\begin{array}{c}72.09 \\
63\end{array}$ & $\begin{array}{c}69.626 \\
4\end{array}$ & $\begin{array}{c}453.6 \\
41\end{array}$ & $\begin{array}{c}29.85 \\
1\end{array}$ & $\begin{array}{c}6.61 \\
28\end{array}$ \\
\hline 1 & $\begin{array}{c}69.9 \\
2\end{array}$ & $\begin{array}{c}68.39 \\
38\end{array}$ & $\begin{array}{c}65.950 \\
3\end{array}$ & $\begin{array}{c}450.7 \\
77\end{array}$ & $\begin{array}{c}32.73 \\
3\end{array}$ & $\begin{array}{c}6.65 \\
49\end{array}$ \\
\hline 2 & 66.3 & $\begin{array}{c}64.70 \\
06\end{array}$ & $\begin{array}{c}62.284 \\
3\end{array}$ & $\begin{array}{c}447.9 \\
31\end{array}$ & $\begin{array}{c}35.59 \\
7\end{array}$ & $\begin{array}{c}6.69 \\
71\end{array}$ \\
\hline 1 & $\begin{array}{c}62.7 \\
3\end{array}$ & $\begin{array}{c}61.04 \\
55\end{array}$ & $\begin{array}{c}58.657 \\
8\end{array}$ & $\begin{array}{c}445.1 \\
03\end{array}$ & $\begin{array}{c}38.44 \\
4\end{array}$ & $\begin{array}{c}6.73 \\
97\end{array}$ \\
\hline 1 & 59.2 & $\begin{array}{c}57.41 \\
72\end{array}$ & $\begin{array}{c}55.060 \\
6\end{array}$ & $\begin{array}{c}445.1 \\
03\end{array}$ & $\begin{array}{c}41.27 \\
2\end{array}$ & $\begin{array}{c}6.78 \\
25\end{array}$ \\
\hline 1 & $\begin{array}{c}55.7 \\
3\end{array}$ & $\begin{array}{c}53.83 \\
45\end{array}$ & $\begin{array}{c}51.512 \\
8\end{array}$ & $\begin{array}{c}442.2 \\
92\end{array}$ & $\begin{array}{c}44.08 \\
26\end{array}$ & $\begin{array}{c}6.82 \\
56\end{array}$ \\
\hline 1 & $\begin{array}{c}52.2 \\
2\end{array}$ & $\begin{array}{c}50.19 \\
63\end{array}$ & $\begin{array}{c}47.914 \\
8\end{array}$ & 439.5 & $\begin{array}{c}46.87 \\
52\end{array}$ & $\begin{array}{c}6.86 \\
9\end{array}$ \\
\hline 7 & $\begin{array}{c}48.8 \\
5\end{array}$ & 45.18 & 43.81 & $\begin{array}{c}436.7 \\
25\end{array}$ & 49.65 & $\begin{array}{c}6.91 \\
26\end{array}$ \\
\hline 1 & $\begin{array}{c}45.3 \\
3\end{array}$ & $\begin{array}{c}43.19 \\
33\end{array}$ & $\begin{array}{c}40.836 \\
7\end{array}$ & $\begin{array}{c}433.9 \\
67\end{array}$ & $\begin{array}{c}52.40 \\
7\end{array}$ & $\begin{array}{c}6.95 \\
65\end{array}$ \\
\hline 1 & $\begin{array}{c}42.3 \\
6\end{array}$ & $\begin{array}{c}40.05 \\
99\end{array}$ & $\begin{array}{c}37.738 \\
2\end{array}$ & $\begin{array}{c}431.2 \\
27\end{array}$ & $\begin{array}{c}55.14 \\
76\end{array}$ & $\begin{array}{c}7.00 \\
08\end{array}$ \\
\hline 2 & $\begin{array}{c}39.4 \\
7\end{array}$ & 37.17 & $\begin{array}{c}34.888 \\
5\end{array}$ & $\begin{array}{c}428.5 \\
04\end{array}$ & 57.87 & $\begin{array}{c}7.04 \\
52\end{array}$ \\
\hline
\end{tabular}

As shown in Figures ( 7 and 8 ) because of the flashing cycle, the outlet brine temperature is decreasing. In addition, the brine flow rate is decreasing due to the distillate formed in each stage. furthermore, the salinity of the product decreases across the stages. That is because the distillate is almost salt free compared to the brine.

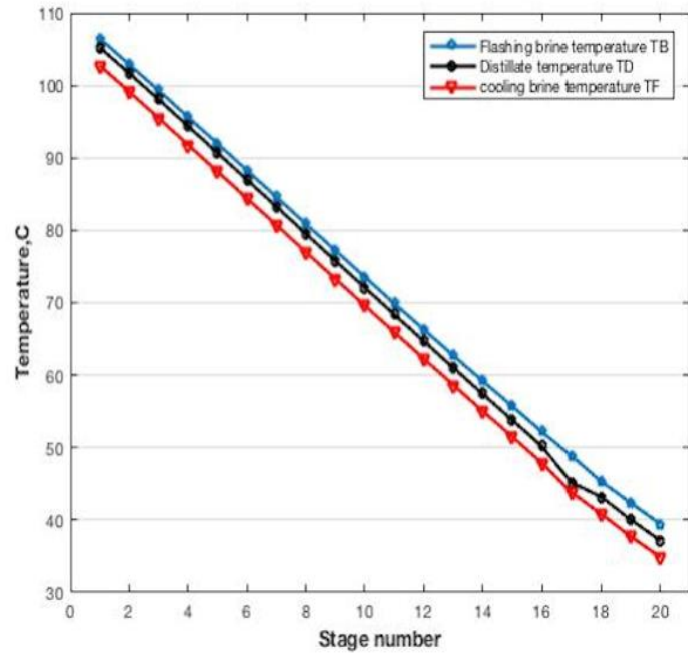

Figure 7: Temperature variation through the stages.

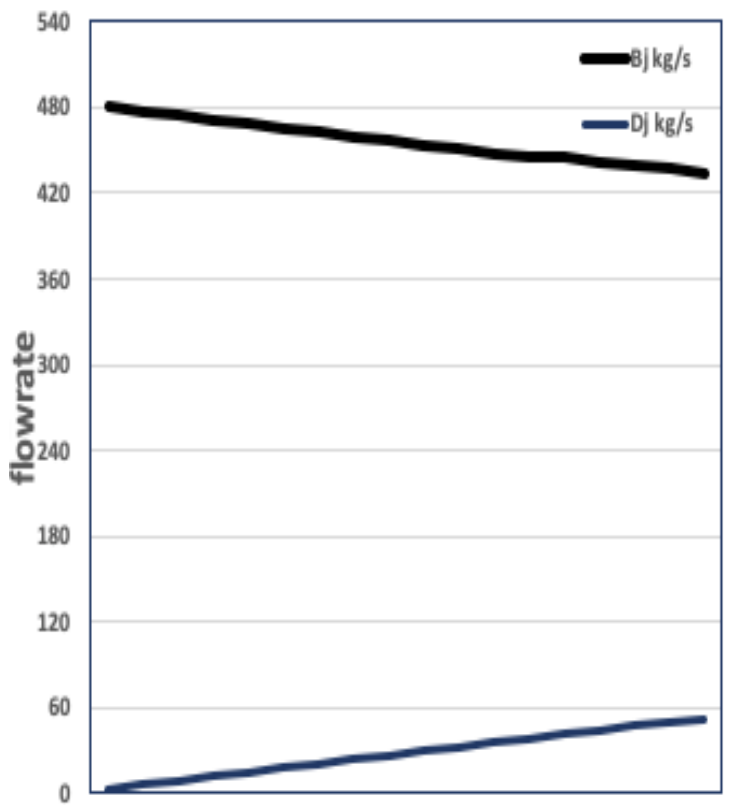

$\begin{array}{llllllllllllllllll}1 & 2 & 3 & 4 & 5 & 6 & 7 & 8 & 9 & 10 & 11 & 12 & 13 & 14 & 15 & 16 & 17 & 18\end{array}$ stage number

Figure 8: Flowrates variation through the stages.

\section{Conclusions}

Steady-state models are useful for evaluating the plant operating conditions; studying the performance of plant. They also provide traces for improving the plant efficiency. The developed model can be used to analyze the MSF-BC desalination process at steady state operation conditions. The developed MATLAB code can be used to perform the performance analysis of MSF-BC desalination plants by calculating the productivity of the plant with profiles of temperatures and flow rates in all stages of the unit. The developed model is valid when compared with commercial software used for the same purpose. The presented model predictions were compared with vendor 
simulation results for BARKA MSF desalination plant reported by Abdul Wahab, (2012), and There was a satisfactory matching between them. Ayoun Mousa MSF desalination plant located in Egypt was used as a case study to predict the performance of the plant.

\section{Nomenclature}

A

BD

BN

BPE

$\mathrm{CW}$

DEM

$D$

DN

$\mathrm{F}$

Fsea

h

L

NEA

$R$

$S$

$\mathrm{T}$

TBT

$U$

W

$\mathrm{X}$

$\lambda s$

$F_{\mathrm{Fj}}$

$\mathrm{V}_{\mathrm{Bj}}$
Heat transfer area, $\mathrm{m}^{2}$

Blow-down mass flow rate, $\mathrm{Kg} / \mathrm{s}$

Flashing brine mass flowrate leaving

stage $\mathrm{N}, \mathrm{Kg} / \mathrm{s}$

Boiling point elevation

Rejected seawater mass flowrate, $\mathrm{Kg} / \mathrm{s}$

Temperature losses due to demister, ${ }^{\circ} \mathrm{C}$

diameter of tube, $m$

Distillate flowrate leaving stage $\mathrm{N}, \mathrm{Kg} / \mathrm{s}$

Make-up seawater mass flow rate, $\mathrm{Kg} / \mathrm{s}$

Intake seawater mass flow rate, $\mathrm{Kg} / \mathrm{s}$

Specific enthalpy, Kcal/Kg

Length of tubes, $m$

Non-equilibrium allowance

Recycled brine mass flow rate, $\mathrm{Kg} / \mathrm{s}$

Specific heat capacity, $\mathrm{Kcal} / \mathrm{Kg}{ }^{\circ} \mathrm{C}$

Temperature, ${ }^{\circ} \mathrm{C}$

Top brine temperature, ${ }^{\circ} \mathrm{C}$

Overall heat transfer coefficient, $\mathrm{Kcal} / \mathrm{m}^{2}$

$$
\mathrm{h} \mathrm{K}
$$

Cooling brine mass flow rate leaving

stage $1, \mathrm{Kg} / \mathrm{s}$

Salinity, wt. \%

Latent heat of steam to the brine heater,

$$
\mathrm{Kcal} / \mathrm{Kg}
$$

Fouling factor at stage $\mathrm{j}(\mathrm{h} \mathrm{m} 2 \stackrel{\mathrm{o}}{\mathrm{C} / \mathrm{Kcal})}$

Linear velocity of brine stream $(\mathrm{ft} / \mathrm{s})$

\section{Subscripts}

b brine

D Distillate product

H Brine heater

j Stage number

$\mathrm{N} \quad$ Last stage of the unit

$\mathrm{R} \quad$ Recycled brine stream

\section{References}

1- El-Dessouky, H. T., \& Ettouney, H. M. (2002). Fundamentals of salt water desalination. Elsevier.

2- Hilal, N., Kim, G. J., \& Somerfield, C. (2011). Boron removal from saline water: a comprehensive review. Desalination, 273(1), 2335.

3- Nair, M., \& Kumar, D. (2013). Water desalination and challenges: the Middle East perspective: a review. Desalination and Water Treatment, 51(10-12), 2030-2040. Vols. 51, 2030-2040.

4- Mandil, M. A., \& Ghafour, E. A. (1970). Optimization of multi-stage flash evaporation plants. Chemical Engineering Science, 25(4), 611-621.
5- Coleman, A. K. (1971). Optimization of a single effect, multi-stage flash distillation desalination system. Desalination, 9(4), 315-331.

6- Soliman, M. A. (1981). A mathematical-model for multistage flash desalination plants. Journal of Engineering Sciences, 7(2), 143-150.

7- Darwish, M. A. (1991). Thermal analysis of multistage flash desalting systems. Desalination, 85(1), 59-79.

8- $\quad$ El-Dessouky, H., Alatiqi, I., \& Ettouney, H. (1998). Process synthesis: the multi-stage flash desalination system. Desalination, 115(2), 155179.

9- $\quad$ Al-bahou, M., Al-Rakaf, Z., Zaki, H., \& Ettouney, H. (2007). Desalination experience in Kuwait. Desalination, 204(1-3), 403-415.

10- Helal, A. M., Medani, M. S., Soliman, M. A., \& Flower, J. R. (1986). A tridiagonal matrix model for multistage flash desalination plants. Computers \& chemical engineering, 10(4), 327342.

11- Hussain, A., Hassan, A., Al-Gobaisi, D., Al-Radif, A., Woldai, A., \& Sommariva, C. (1993). Modeling, simulation, optimization and control of multistage flash (MSF) desalination plants Part2: Modeling and simulation. Desalination, 92, 21-41.

12- Aly, S.E. and Fathalah, K. (1995). MSF - a mathematical model, Proc. IDA World Congress, Abu Dhabi, 203-226.

13- El-Dessouky, H., Shaban, H. I., \& Al-Ramadan, H. (1995). Steady-state analysis of multi-stage flash desalination process. Desalination, 103(3), 271287.

14- Rosso, M., Beltramini, A., Mazzotti, M., \& Morbidelli, M. (1997). Modeling multistage flash desalination plants. Desalination, 108(1-3), 365374.

15- Thomas, P. J., Bhattacharyya, S., Patra, A., \& Rao, G. P. (1998). Steady state and dynamic simulation of multi-stage flash desalination plants: A case study. Computers \& chemical engineering, 22(10), 1515-1529.

16- Aly, N. H., \& El-Figi, A. K. (2003). Thermal performance of seawater desalination systems. Desalination, 158(1-3), 127-142.

17- Tanvir, M. S., \& Mujtaba, I. M. (2006). Modelling and simulation of MSF desalination process using gPROMS and neural network based physical property correlation. Computer aided chemical engineering, 21(A), 315.

18- Abdel-Jabbar, N. M., Qiblawey, H. M., Mjalli, F. S., \& Ettouney, H. (2007). Simulation of large capacity MSF brine circulation plants. Desalination, 204(1-3), 501-514.

19- Alasfour, F. N., \& Abdulrahim, H. K. (2009). Rigorous steady state modeling of MSF- BR desalination system. Desalination and Water Treatment, 1(1-3), 259-276. 
20- Hawaidi, E. A., \& Mujtaba, I. M. (2010). Sensitivity of brine heater fouling on optimization of operation parameters of MSF desalination process using PROMS. In 20th European Symposium on Computer Aided Process Engineering-ESCAPE20.

21- Said, S. A. R. (2013). MSF process modelling, simulation and optimisation: impact of noncondensable gases and fouling factor on design and operation.(Doctoral dissertation, University of Bradford.

22- Ali, M. B., \& Kairouani, L. (2014). Solving equations describing the steady-state model of MSF desalination process using Solver Optimization Tool of MATLAB software. Desalination and Water Treatment, 52(40-42), 7473-7483.

23- Al-Hamahmy, M., Fath, H. E., \& Khanafer, K. (2016). Techno-economical simulation and study of a novel MSF desalination process. Desalination, 386, 1-12.

24- Wael.A.(2017, september).Modelling and Simulation of Multistage Flash Desalination Plants. In Libyan Journal for Engineering Research (LyJER),ISSN 2522- 6967.

25- Al-Shayji, K. A. M. (1998). Modeling, simulation, and optimization of large-scale commercial desalination plants (Doctoral dissertation, Virginia Tech).

26- Abdul-Wahab, S. A., Reddy, K. V., Al-Weshahi, M. A., Al-Hatmi, S., \& Tajeldin, Y. M. (2012). Development of a steady-state mathematical model for multistage flash (MSF) desalination plant. International Journal of Energy Research, 36(6), 710-723.

27- Nafey, A. S. (2005). Simulation of solar heating systems-an overview. Renewable and Sustainable Energy Reviews, 9(6), 576-591.

28- Ettouney, H., El-Dessouky, H., \& Al-Juwayhel, F. (2002). Performance of the once- through multistage flash desalination process. Proceedings of the Institution of Mechanical Engineers, Part A: Journal of Power and Energy, 216(3), 229-241. Vols. 229-242 (2.

29- Helal, A. M., El-Nashar, A. M., Al-Katheeri, E., \& AlMalek, S. (2003). Optimal design of hybrid RO/MSF desalination plants Part I: Modeling and algorithms. Desalination, 154(1), 43-66.

30- Perry, R. H., Green, D. W., \& Maloney, J. O. (1997). Perry's chemical engineers' handbook.

31- Rosso, M., Beltramini, A., Mazzotti, M., \& Morbidelli, M. (1997). Modeling multistage flash desalination plants. Desalination, 108(1-3), 365374. 